\title{
Environmental Scanning Mechanism and Its Effects on the Performance: Evidence from UAE
}

\author{
Mansour S. M. A. M. Lotayif ${ }^{1}$ \\ ${ }^{1}$ Faculty of Commerce, Beni-Suif University, Egypt \\ Correspondence: Mansour S. M. A. M. Lotayif, Faculty of Commerce, Beni-Suif University, Egypt. E-mail: \\ Mansourlotayif@hotmail.com
}

Received: October 25, 2017

Accepted: November 28, 2017

Online Published: December 20, 2017

doi:10.5539/ijbm.v13n1p190

URL: https://doi.org/10.5539/ijbm.v13n1p190

\begin{abstract}
The current Research aims at figuring out relationships between performance (as measured by ROE and PM) and demographics, interest in scanning, kinds of scanning, scanning frequency, sources of scanning (impersonal and personal), and obstacles of scanning. Experiences of 292 UAE executives have been used to fulfill these objectives. Via SPSS package release ten and seventeen, multivariate analysis (e.g. Multiple Regression), bivariate analysis (e.g. WSRT), and univariate analysis (e.g. descriptive analysis like mean, percentage, and sum) were conducted to explore the network of relationships amongst variables. Significant relationships between performance (as measured ROE) and interest in scanning, scanning frequency, sources of scanning (impersonal), and obstacles of scanning are existed. Significant relationships between performance (as measured by PM) and interest in scanning, scanning frequency, sources of scanning (personal), and sources of scanning (impersonal) are also existed. Finally, the current study revealed that UAE businesses are conducting regular, proactive, and hoc scanning more often than irregular, reactive, and primitive scanning.
\end{abstract}

Keywords: Environmental Scanning, Performance, and UAE

\section{Introduction}

It generally conceded in business practice that, scanning the external and internal environments is a prerequisite to figure out potential opportunities and threats before formulating the corporate competitive strategy (Toit, 2005; Albright, 2004; and Wheelen and Hunger, 1992) that utilizes the strengths and tries to overcome the weaknesses. The degrees of success any organization can achieve appear to be a function of how effective interactive system the organization has with its environment (Hambrick, 1982; Pfeffer\&Salancik 1978). Cheng, (2014) and Toit, (2005) did define the environment as anything found outside the boundaries of the company, or al sets of element that are independent of the organization and are of importance for its success. Actually, organizations are creatures of their surrounding environments, spending much time to learn how to deal with the traumas, vagaries and opportunities created by that environment (Douglas, 1994, p. 703). Nowadays, information collection process has not become an easy task, as firms are working in more complex surroundings than ever before (Van de Ven and Joyce, 1981) that leads to an explosion of the quantity and quality of available information (Subramanian et al., 1993). In the other side, this process is more complicated and challenged by many obstacles. Sawyerret al.(2000); Mrema (1987); Adegbite (1986); Anastoset al. (1980); and Flores (1972) found that research on planning in developing nations has indicated the lack of information as a core reason for the disappearance of formal corporate planning activities in these countries. Also, the lack of infrastructures required for data gathering is another problem in this perspective (Nwachukwu, 1985; and Siffin, 1976).

Before going further in any direction, a common understanding of external environmental scanning (EES) process should be put forward first. EES is a process that scanning and collecting information about events or relationships with a firm's outside environment that would (a) aids top management in leading the company (Elenkov, 1997), (b) inspects and understands related information to detect external opportunities and external threats. It is the radar to detect environmental signals (Albright, 2004), and (c) helps assist of determining the firm's future courses of action (Kamangar, 2013, Aguilar, 1967). EES mechanism includes to monitor, to evaluate, and to disseminate information from the external environment to key executives within their firms (Snyder, 1981) for taking essential organizational decisions (Aguilar, 1967). Therefore, EES is a strategic management tool that links organizations abilities to their external environments. Annex, $=$ EES function as an 
effective tool to deal with uncertainties and to form adaptive strategies via using tools like SWOT and PESTEL analysis (Kamangar,2013, Toit, 2005; Albright, 2004; Sawyerr et al., 2000; Hagen \& Amin, 1995; Zahra, 1987; Hax\&Majluf, 1984; Daft \&Weick, 1984; Hambrick, 1982; Porter, 1980; Hofer \&Schendel, 1978; Pfeffer and Salancik, 1978; Aguilar, 1967).

Logically, all data sources could be used in EES. More specifically, sources of strategic information have been classified into two broad categories: external and internal, and further sub-classified into personal and impersonal (Hidayat, 2015; Toit, 2005; Sawyerret el al., 2000, p. 100; Aguilar, 1967). External sources of information are those originating outside the organization while internal sources created from within the organization. Personal sources of information created from personal contacts with people within and outside the organization while impersonal sources created from non-personal sources such as documents etc. (Daft \&Weick, 1984; Aguilar, 1967). All these sources are addressed in the current study.

\section{Previous Work}

Lawrence and Lorsch (1967) have been among the pioneers who pinpoint the tie between the environmental scanning activities and performance. Compiling evidences have shown that chief managers in high-performing firms scanned their surroundings more comprehensively and more frequently compared with their counterparts in low-performing firms (Daft et al., 1988). Smith et al., (1991); and Zajac and Shortell, (1989) findings in service and product organizations support the linkage between performance and environmental scanning mechanism. Moreover, Subramanian et al., (1993) findings, also, found evidence that support the relationship between firm's performance (as measured by profitability and growth) and sophisticated scanning schemes. Additionally, Auster and Choo (1994) and Daft et al., (1988) have examined the level of uncertainty perceived in the task and remote sectors of the environment. Literature wise, task environment (TE) means the most nearby environment of the firm with elements that have a direct influence on the firm's performance and, in turn, are influenced by firm' activities such as customer, competitor, and supplier (Grant, 1998; Asheghian and Ebrahimi, 1990; and Dill, 1958). Meanwhile, remote environmental (RE) factors include those sectors of the environment that have an indirect influence on the firm's performance, such as the governmental, economical conditions, technological, and socio-cultural sectors (Sawyerret et al., 2000; Grant, 1998; Auster and Choo, 1994; Wheelen and Hunger, 1992; Asheghian and Ebrahimi, 1990; Daft et al., 1988; and Preble et al., 1988).

In this perspective, Auster and Choo's (1994) results provided full support for the importance of the task environment sectors. However, Daft et al., (1988) provided partial support for that importance to decision makers. In the same line of logic, Sawyerret et al., (2000) found that environmental scanning frequency does not vary significantly for the task and remote environments. However, remote environment (RE) received greater attention from decision-makers (Auster \& Choo, 1994; Daft et al., 1988; Preble et al., 1988). One explanation behind that could be the sectors in the task environment are most relevant for goal setting and goal attainment and as such should receive greater attention from executives (Grant, 1998; Boultonet et al., 1982; Dill, 1958). To bridge part of this gap in the literature, the current study attempts to address both RE and TE in UAE context and their relationships with performance.

Addressing the topic from a different perspective in hotel context, Costa and Teare (2000) have distinguished between two main areas affecting the development of a formal environmental scanning process: (a) decision making and managerial attitudes related. It includes fluctuation in the current organizational culture, company perspectives towards the importance of information, its dissemination and sharing with colleagues.(b) environmental scanning process related e.g. its quality, objectivity and formatting of the information produced; the organization of the scanning process; the system to store, process and disseminate the information; and the definition of information needs and sources.

Most recently, Manuel, (2005) promoted for the use of seven factors i.e. competitive, market, technology, regulatory, resource, broad, and other factorsin a Malaysian context juxtapose with USA practices in environmental scanning. It worth mentioning that competitive factors are all information connected with competitor (present and potential) including their moves, decisions, strategies, plans, strength, and weaknesses. Market factors are all information about the markets excluding matters related to competition. It includes market potential, customers' needs and taste, distribution channels, and promotion reactions. Technology factors are all information about present and potential commodities and production techniques. For regulatory factors, it includes all information regarding regulations that could affect firm' operations, such as e.g. regulatory and labor agencies. Resource factors are all information on financial, labor and raw material markets that affect tangibles and intangibles, resources and services procured by the firm for carrying out its operations. Broad issues are all information on demographic, social, economic and political trends. Finally, other factors are all the information 
on factors not included in any of the earlier categories.

Notably, the cyclical link between performance outcomes and scanning activities has been, with some exceptions (for example, Milliken and Lant, 1991), ignored in the literature (Elenkov, 1997, p. 115). From this perspective, the idea for this study has been ignited as a result of Subramanian et al., (1993) recommendation of replicating his study by using bigger and different samples would help gain a better perspective on comprehensive environmental scanning practices and its link with company performance. Before that, Kim and Lim (1988) addressed and confirmed the same desire for enlarging the sample in another context for the sake of examining and enhancing the external validity. Consequently, the current research is an endeavor in this perspective in UAE context as Sawyerret et al., (2000) recommended replicating what they have found in the Nigerian market in another developing country in order to add external validity. In other words, the need for more sample size to reexamines and updating concepts that have been explored in previous researches was the igniting power behind pursuing the current study aims.

In the current study, a more comprehensive approach is deployed as it addresses most of the commonly agreed variables in environmental scanning's literature. More specifically, two subscales i.e. frequency of scanning, and interest in scanning are used to measure environmental scanning (Sawyerret et al., 2000; Ebrahimi, 2000; Elenkov, 1997; Boyd and Fulk, 1996; Sawyerr, 1993; Daft et al., 1988; and Farhet al., 1984). The fact of the matter, Hambrick (1981) promoted for three subscales to measure environmental scanning: frequency of scanning, interest in scanning, and number of hours spent scanning. However, Farhet al., (1984) have verified the reliability and validity of these subscales and found number of hours not reliable. Performance is measured by ROE rate and profit margin (PM) as used by Sawyerret et al., (2000). Environmental obstacles are measured by government bureaucracy, information in a different language, inadequate management education/training, uncertainty regarding government long-term policies, absence of data sources, and the quality of available information, as identified from corporate planning literature especially in developing countries (Elenkov, 1997; Mrema, 1987; Adegbite, 1986; Fubara, 1986; and O'Shaughnessy, 1985). Scanning sources are measured by trade journals, reports of trade and professional associations, customers, company-sponsored surveys, scientific journals, governmental publications (Subramanian et al., 1993), and newspaper (Jain, 1984). Finally, demographics are the firm size that measured by number of employees using Sawyerr's (1985) classification, which are: (a) small firms are those with 50 employees or less; (b) medium firms are those with 51-1000 employees; and big firms are those with 1001 and more. However, sales volume could be another viable alternative to measure firm size as suggested by Subramanian et al., (1993). Respondents' positions, ages, educational levels, and number of years in business i.e. experience are another demographic variables as suggested by Lotayif (2004), Lotayif and El-Ragal (2004), Lotayif (2003) and Hambrick and Mason, (1984).

\section{Study Aims}

The current study aims at achieving the following aims:

(1) Exploring the causality relationship between the environmental scanning (i.e. demographics, interest in scanning, scanning frequency,kinds of scanning, sources of scanning (impersonal), sources of scanning (personal), and obstacles of scanning) and performance as measured by ROE and PM. Therefore, the following seven sub-aims could be driven from this broad aim:

A. Exploring the relationship between demographics and performance (measured by ROE and PM).

B. Exploring the relationship between interest in scanning and performance (measured by ROE and PM).

C. Exploring the relationship between frequency of scanning and performance (measured by ROE and PM).

D. Exploring the relationship between kinds of scanning and performance (measured by ROE and PM).

E. Exploring the relationship between sources of impersonal scanning, and performance (measured by ROE and PM).

F. Exploring the relationship between sources of personal scanning, and performance (measured by ROE and PM).

G. Exploring the relationship between obstacles of scanning, and performance (measured by ROE and PM).

(2) Shedding light on the adopted environmental scanning in UAE.

\section{StudyHypotheses}

The above mentioned aimswill be achieved via the following hypotheses. Hypotheses from $\left(\boldsymbol{H}_{1}, \boldsymbol{H}_{1_{A}}\right)$ to $\left(\boldsymbol{H}_{7}\right.$, 
$\left.\boldsymbol{H}_{7 A}\right)$ are designed for the first research's aim. For the second research's aim, hypotheses $\left(\boldsymbol{H}_{8}\right),\left(\boldsymbol{H}_{9}\right)$, and $\left(\boldsymbol{H}_{9}\right)$ are designed.

$\boldsymbol{H}_{1}$ : "There is a significant relationship between demographics (e.g. age, education level, executive experience, business experience, and number of employees) and company's performance as measured by return on equity" $\boldsymbol{H}_{1_{A}}$ : "There is a significant relationship between $\underline{\text { demographics }}$ (e.g. age, education level, executive experience, business experience, and number of employees) and company's performance as measured by profit margin"

$\boldsymbol{H}_{2}$ :"There is a significant relationship between interest in scanning and company's performance as measured by return on equity"

$\boldsymbol{H}_{2 A}$ :"There is a significant relationship between interest in scanning and company's performance as measured by profit margin"

$\boldsymbol{H}_{3}:$ "There is a significant relationship between scanning frequency and company's performance as measured by return on equity"

$\boldsymbol{H}_{3 A}$ :"There is a significant relationship between scanning frequency and company's performance as measured by profit margin"

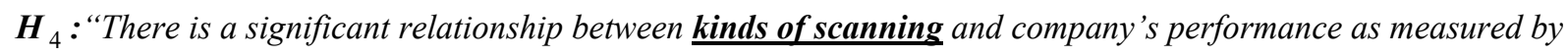
return on equity"

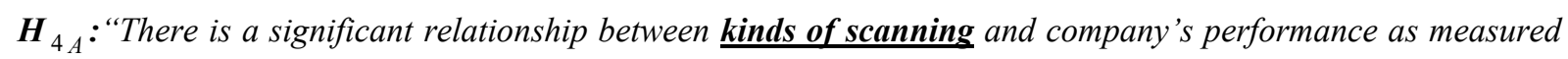
by profit margin"

$\boldsymbol{H}_{5}$ :"There is a significant relationship between impersonal source of scanning and company's performance as measured by return on equity",

$\boldsymbol{H}_{5 A}$ : "There is a significant relationship between impersonal source of scanning and company's performance as measured by profit margin"

$\boldsymbol{H}_{6}$ :"There is a significant relationship between personal sources of scanning and company's performance as measured by return on equity"

$\boldsymbol{H}_{6_{A}}$ : "There is a significant relationship between personal sources of scanning and company's performance as measured by profit margin"

$\boldsymbol{H}_{7}$ :"There is a significant relationship between obstacles of scanning and company's performance as measured by return on equity" 
$\boldsymbol{H}_{7 A}$ : "There is a significant relationship between obstacles of scanning and company's performance as measured by profit margin"

$\boldsymbol{H}_{8}$ : "UAE businesses conducting regular more frequently than irregular scanning".

$\boldsymbol{H}_{9}$ : "UAE businesses conducting reactive more frequently than proactive scanning".

$\boldsymbol{H}_{9}$ : "UAE businesses conducting hoc scanning more frequently thanprimitive".

\section{Study Methodology}

It includes: (1) the deployed research philosophy (2) sample and population (3) way(s) of data collection; (4) the used statistical packages and statistical techniques. Firstly; for research philosophy, qualitativeapproach through using a structured questionnaire was deployed. Secondly, a convenience sample of 350 executives in UAEhas been use in the current research. Thirdly, a seven parts structured questionnaire with seven-point Likert scale was deployed, as shown in Appendix (A). These seven parts are demographics (e.g. age, education, executive experience, business experience, and number of employees), interest in scanning (from X2 to X8), frequency of scanning (from X10 to X16), performance measures (X18, and X19), kinds of scanning (from X21 to X26), sources of scanning (from X28 to X38 for impersonal sources and from X41 to X56 for personal sources), and obstacles of scanning (from X58 to X64). The questionnaire and the covering letter were sent to every executive. The response rate was 83.4 percent, as the completed and returned questionnaires were292 out of 350 questionnaires. Finally, SPSS release seventeen was used as data analysis software. Multiple regression, Wilcoxon Signed Ranks Test (WSRT), and descriptive techniques were deployed.

\section{The Study Findings}

In this part of the study, sample normality, regressors multi-collinearity, scale validity, instrument reliability, hypotheses testing, conclusion and recommendations will be discussed.

\subsection{Normality, Multi-Collinearity, Validity, and Reliability}

Data distribution's shape is considered normal when the sample size is bigger than 30 cases (Lotayif, 2017a, 2017b, 2016, 2015a and 2015b and Ortuzar and Willumsen, 1994). Consequently, normality dimension is assumed, as sample's size is 292 cases in the current study. Statistically, instrument and concepts are considered reliable when the value of Cronbach alpha coefficient is bigger than 60 percent (Lotayif, 2014, 2005, Lotayif and El-Ragal,, 2004,Lotayif, 2004a, 2004b, 2003a, and 2003b and Foster, 2001, p. 228; Teo and King, 1996; and Malhotra, 1993, p. 308).

Table 1. Reliability of Instrument and Concepts

\begin{tabular}{lllll}
\hline Instrument and Concepts & $\mathrm{N}$ & N of Items & Alpha \\
\hline - & Instrument & 292 & 65 & .9160 \\
- $\quad$ Interest in Scanning & 292 & 7 & .7290 \\
- $\quad$ Scanning Frequency & 292 & 7 & .7958 \\
- $\quad$ Kinds of Scanning & 292 & 6 & .633 \\
- $\quad$ Source of Scanning (impersonal) & 292 & 11 & .792 \\
- $\quad$ Source of Scanning (personal) & 292 & 16 & .928 \\
\hline
\end{tabular}

As indicated in Table (1), Cronbach alpha coefficients are 91.6, 72.9, 79.5, 63.3, 79.2, 92.8, and 90 percentfor the whole instrument's items, interest in scanning, scanning frequency, kinds of scanning, source of scanning (impersonal), source of scanning (personal), and obstacles of scanning concepts respectively. Therefore, reliability dimension in the current study is supported. Multi-collinearity amongst study's regressors is supported, as all correlations' coefficients show values less than unity, as shown in Tables $(2,3,4,5,6$, and 7). 
Table 2. Multi-collinearity of Regressors (Demographics)

\begin{tabular}{|c|c|c|c|c|c|}
\hline \multirow[t]{3}{*}{ Independent Variables } & \multicolumn{5}{|c|}{ Independent Variables } \\
\hline & \multirow[t]{2}{*}{ Age } & \multirow[t]{2}{*}{ Education } & Employee & Business & Number \\
\hline & & & Experience & Experience & Employees \\
\hline Age & $\ldots$ & & & & \\
\hline Education & .145 & $\ldots$ & & & \\
\hline Employee Experience & .578 & .107 & $\ldots$ & & \\
\hline Business Experience & .134 & -.056 & .368 & $\ldots$ & \\
\hline Number of Employees & -.104 & .040 & .083 & .424 & $\ldots$ \\
\hline \multicolumn{6}{|l|}{ Note: - } \\
\hline Number of matri & $n(n-1)$ & re $n=$ Numb & independent & bles $\{5(5-$ & 10 \} Variables. \\
\hline
\end{tabular}

Table 3.Multi-collinearity of Regressors( Interest in Scanning)

\begin{tabular}{|c|c|c|c|c|c|c|c|}
\hline \multirow[t]{2}{*}{ Independent Variables } & \multicolumn{7}{|c|}{ Independent Variables (Xs) } \\
\hline & 2 & 3 & 4 & 5 & 6 & 7 & 8 \\
\hline $\mathrm{X} 2$ & \multicolumn{7}{|l|}{$\ldots$} \\
\hline $\mathrm{X} 3$ & .575 & \multicolumn{6}{|l|}{$\cdots$} \\
\hline $\mathrm{X} 4$ & .387 & .415 & \multicolumn{5}{|l|}{$\ldots$} \\
\hline $\mathrm{X} 5$ & .224 & .345 & .413 & \multicolumn{4}{|l|}{$\cdots$} \\
\hline X6 & .295 & .347 & .287 & .470 & \multicolumn{3}{|l|}{$\cdots$} \\
\hline X7 & .350 & .429 & .333 & .352 & .368 & \multicolumn{2}{|l|}{$\ldots$} \\
\hline $\mathrm{X} 8$ & .239 & .322 & .377 & .394 & .400 & .439 & $\ldots$ \\
\hline \multicolumn{8}{|l|}{ Note: - } \\
\hline Interest in Scann & $\mathrm{X} 2$ tc & as sho & n Appe & A). & & & \\
\hline
\end{tabular}

Table 4.Multi-collinearity of Regressors (Frequency of Scanning)

\begin{tabular}{|c|c|c|c|c|c|c|c|}
\hline \multirow[t]{2}{*}{ Independent Variables } & \multicolumn{7}{|c|}{ Independent Variables (Xs) } \\
\hline & 10 & 11 & 12 & 13 & 14 & 15 & 16 \\
\hline X10 & $\ldots$. & & & & & & \\
\hline X11 & .624 & $\ldots$. & & & & & \\
\hline $\mathbf{X 1 2}$ & .547 & .661 & $\cdots$. & & & & \\
\hline X13 & .354 & .512 & .451 & $\ldots$ & & & \\
\hline X14 & .427 & .549 & .469 & .594 & $\cdots$. & & \\
\hline X15 & .470 & .480 & .607 & .553 & .566 & $\ldots$. & \\
\hline X16 & .338 & .462 & .492 & .492 & .422 & .578 & $\ldots$. \\
\hline \multicolumn{8}{|l|}{ Note: - } \\
\hline$>\quad$ Frequency of Sca & from $Y$ & to $\mathrm{X} 1$ & vn in $\mathrm{A}$ & $\mathrm{x}(\mathrm{A})$. & & & \\
\hline
\end{tabular}

Table 5. Multi-collinearity of Regressors (Impersonal Sources)

\begin{tabular}{|c|c|c|c|c|c|c|c|c|c|c|c|}
\hline \multirow{2}{*}{$\begin{array}{l}\text { Independent Variables } \\
\text { Regressors }\end{array}$} & \multicolumn{11}{|c|}{ Independent Variables } \\
\hline & 28 & 29 & 30 & 31 & 32 & 33 & 34 & 35 & 36 & 37 & 38 \\
\hline $\mathrm{X} 28$ & $\ldots$. & & & & & & & & & & \\
\hline $\mathbf{X} 29$ & .831 & $\ldots$. & & & & & & & & & \\
\hline $\mathbf{X 3 0}$ & .631 & .666 & $\ldots$. & & & & & & & & \\
\hline X31 & .537 & .544 & .496 & $\ldots$. & & & & & & & \\
\hline $\mathbf{X 3 2}$ & .536 & .544 & .598 & .437 & $\ldots$. & & & & & & \\
\hline X33 & .447 & .488 & .533 & .330 & .619 & $\ldots$. & & & & & \\
\hline X34 & .429 & .460 & .456 & .301 & .526 & .625 & $\ldots$. & & & & \\
\hline X35 & .519 & .513 & .376 & .487 & .342 & .346 & .427 & $\cdots$ & & & \\
\hline X36 & .500 & .499 & .394 & .279 & .419 & .442 & .504 & .693 & $\ldots$. & & \\
\hline $\mathbf{X 3 7}$ & .449 & .443 & .392 & .267 & .381 & .461 & .502 & .643 & .822 & $\ldots$. & \\
\hline X38 & .460 & .455 & .363 & .309 & .429 & .488 & .537 & .623 & .706 & .736 & .... \\
\hline
\end{tabular}


Table 6. Multi-collinearity of Regressors( Personal Sources)

\begin{tabular}{|c|c|c|c|c|c|c|c|c|c|c|c|c|c|c|c|c|}
\hline \multirow[t]{2}{*}{ IVs } & \multicolumn{16}{|c|}{ Independent Variables (Xs) } \\
\hline & 41 & 42 & 43 & 44 & 45 & 46 & 47 & 48 & 49 & 50 & 51 & 52 & 53 & 54 & 55 & 56 \\
\hline \multicolumn{17}{|l|}{$\bar{X} 41$} \\
\hline $\mathrm{X} 42$ & .789 & $\ldots$ & & & & & & & & & & & & & & \\
\hline $\mathrm{X} 43$ & .712 & .788 & $\ldots$ & & & & & & & & & & & & & \\
\hline X44 & .719 & .779 & .724 & $\ldots$ & & & & & & & & & & & & \\
\hline $\mathrm{X} 45$ & .740 & .748 & .753 & .783 & $\ldots$ & & & & & & & & & & & \\
\hline $\mathrm{X} 46$ & .685 & .633 & .646 & .739 & .726 & $\ldots$ & & & & & & & & & & \\
\hline $\mathrm{X} 47$ & .655 & .684 & .680 & .692 & .702 & .686 & $\ldots$ & & & & & & & & & \\
\hline $\mathrm{X} 48$ & .657 & .606 & .617 & .655 & .747 & .752 & .706 & $\ldots$ & & & & & & & & \\
\hline $\mathrm{X} 49$ & .638 & .633 & .639 & .630 & .691 & .663 & .722 & .774 & $\ldots$ & & & & & & & \\
\hline $\mathrm{X} 50$ & .565 & .548 & .580 & .590 & .669 & .630 & .636 & .747 & .710 & $\ldots$ & & & & & & \\
\hline X51 & .616 & .587 & .590 & .658 & .674 & .664 & .655 & .676 & .657 & 669 & $\ldots$ & & & & & \\
\hline X52 & .546 & .562 & .660 & .581 & 639 & .561 & .670 & .623 & .632 & .661 & .704 & $\ldots$ & & & & \\
\hline X53 & .638 & .626 & .616 & .708 & .679 & .674 & .643 & .647 & .642 & .678 & .727 & .657 & $\ldots$ & & & \\
\hline X54 & .617 & .645 & 679 & .710 & .695 & .664 & .689 & .650 & .652 & .686 & .687 & .664 & .843 & $\ldots$ & & \\
\hline X55 & 649 & .664 & .678 & .737 & .719 & .671 & .677 & .680 & .688 & .629 & .642 & .714 & .781 & .809 & $\ldots$ & \\
\hline X56 & .530 & .578 & .646 & .611 & .613 & .607 & .690 & .627 & .648 & .636 & .617 & .722 & .644 & .699 & .757 & $\ldots$ \\
\hline \multicolumn{17}{|c|}{ Note: - Personal Sources from X41 to X56, as shown in Appendix (A). } \\
\hline
\end{tabular}

Table 7. Multi-collinearity of Regressors (Obstacles of Scanning)

\begin{tabular}{|c|c|c|c|c|c|c|c|}
\hline \multirow[t]{2}{*}{ Independent Variables } & \multicolumn{7}{|c|}{ Independent Variables (Xs) } \\
\hline & 58 & 59 & 60 & 61 & 62 & 63 & 64 \\
\hline $\mathrm{X} 58$ & $\ldots$ & & & & & & \\
\hline X59 & .553 & $\ldots$ & & & & & \\
\hline X60 & .537 & .595 & $\ldots$ & & & & \\
\hline X61 & .520 & .483 & .677 & $\ldots$ & & & \\
\hline X62 & .417 & .459 & .574 & .583 & $\ldots$ & & \\
\hline X63 & .519 & .594 & .600 & .591 & .611 & $\ldots$ & \\
\hline X64 & .500 & .477 & .529 & .472 & .569 & .644 & $\ldots$ \\
\hline \multicolumn{8}{|l|}{ Note: - } \\
\hline$>\quad$ Obstacles of Sca & $\mathrm{X} 58 \mathrm{t}$ & s show & endix & & & & \\
\hline
\end{tabular}

For instrument's validity, grouped discussions with colleagues and fellow academics suggested some minor paraphrasing and typo amendments. Literally, validity refers to the extent to which a test measures the concept(s) that it intends or claims to measure (Bryman and Cramer, 1999; Rust and Golomok, 1999; Kline, 1997; and Nunnally, 1978). Unlike reliability, there is no single figure which indicates test validity (Kline, 1997). Stodnicket al.(2008); Saravananet et al., (2007); El-Ragal, (2001); Keilet al.(2000); Ravichandran and Rai, (2000); Bryman and Cramer, (1999); Rust and Golomok, (1999); Chan et al., (1998); Kline, (1997); Wonnacott and Wonnacott, (1990); Ghiselliet al. (1981); and Nunnally, (1978) distinguish between types of validity. These types are face, contents, predictive (criterion-related validity), construct, concurrent, convergent, divergent, and discriminant validities.

\subsection{Hypotheses Testing}

As indicated in Table 8 and based on Multiple Regression (MR) results, there are significant relationships between performance as measured by return on equity (ROE) and interest in scanning, scanning frequency, sources of scanning (impersonal), and obstacles of scanning, as $p<0$. 05. Consequently, the alternative hypotheses $\boldsymbol{H}_{2}, \boldsymbol{H}_{3}, \boldsymbol{H}_{5}$, and $\boldsymbol{H}_{7}$ are supported. However, no relationships are existed between performance as measured by ROE and demographics, kinds of scanning, and sources of scanning (personal) as $p=0.103,0.244$, and0.354 $>0.05$ respectively. Therefore, the alternative hypotheses $\boldsymbol{H}_{1}, \boldsymbol{H}_{4}$, and $\boldsymbol{H}_{6}$ are not supported. The 
most remarkable things are:

- Interest of scanning, its frequency, the impersonal sources of scanning, and obstacles of scanning affect the performance of profit oriented businesses.

- The process of data entry did not affected by the process of entry order, as Durbin-Watson test reported values $>1.4$ for all dependent variables, as shown in Table (8).

- The explanation powers of these models are weak, as "R square" and "adjusted R" values indicate. More specifically, these four IVs (i.e. interest in scanning, scanning frequency, sources of scanning (impersonal), and obstacles of scanning $\}$ are responsible only for $0.141,0.049,0.142$, and 0.050 respectively of the behavior of DV (performance as measured by ROE).However, if the adjusted R square has been taken into consideration, the magnitude of IVs shrink tosmall proportions, as shown in Table 8.

Table 8.Multiple Regressions between Scanning Concepts and Performance \{Measured by ROE)\}

\begin{tabular}{|c|c|c|c|c|c|c|}
\hline & $\mathbf{F}$ & P-value & $\mathbf{R}$ & R Square & $\begin{array}{l}\text { Adjusted R } \\
\text { Square }\end{array}$ & Durbin-Watson \\
\hline Demographics & 1.847 & 0.103 & 0.176 & .031 & 0.034 & 1.582 \\
\hline Interest in Scanning & 6.681 & $0.001 * * *$ & 0.376 & .141 & .120 & 1.780 \\
\hline Scanning Frequency & 2.086 & $0.045^{* * *}$ & 0.221 & .049 & .025 & 1.616 \\
\hline Kinds of Scanning & 1.328 & 0.244 & 0.165 & .027 & .007 & 1.541 \\
\hline Sources of Scanning (impersonal) & 4.228 & $0.000 * * *$ & 0.377 & .142 & .109 & 1.624 \\
\hline Sources of Scanning (personal) & 1.100 & 0.354 & 0.246 & .061 & .005 & 1.573 \\
\hline Obstacles of Scanning & 2.126 & $0.040^{* * *}$ & 0.223 & .050 & .026 & 1.511 \\
\hline \multicolumn{7}{|l|}{ Notes:- } \\
\hline \multicolumn{7}{|c|}{$>\quad(* * *)$ There is a significant relationship between at least one of the independent variables and model dependent variable as $p<0.05$. } \\
\hline \multicolumn{7}{|c|}{$>\quad \mathbf{R}$ Square $=$ indicates the effect the independent variables have on the dependent one in the sample. } \\
\hline \multicolumn{7}{|c|}{$>\quad$ Adjusted R Square $=$ reflects the model goodness of fit for the population. } \\
\hline \multicolumn{7}{|c|}{$\begin{array}{l}\text { Durbin-Watson is a test to indicate the effect of data entry order in the analysis, therefore if it is }>1.4 \text { it means the order has no effect } \\
\text { on the analysis and if it is less it means the order has affected the analysis (Stat graphics 2000). }\end{array}$} \\
\hline
\end{tabular}

Statistically, if the MR model is significant it does not mean that all the IVs within the regression equation have significant relationships with the dependent variable, but it does, explicitly, mean that only (at least) one significant relationship exist (Ashour, 1993). Therefore it is necessary to determine the effect that each IV has in the MR equation. More specifically, competition (X3) and economical scanning (X6) are the only two independent variables (within the construct of scanning interest from X2 to X8) that have significant relationships with performance as measured by ROE, as $p=0.002$, and 0.009 . Governmental reports (X32) is the only independent variable (within the construct of impersonal sources of scanning from X28 to X38) that has significant relationship with performance as measured by ROE, as $p=0.020$. Finally, uncertainty regarding government long-term policies(X61) is the only independent variable (within obstacles of scanning from X58 to X64) that has significant relationship with performance as measured by ROE, as $p=0.018$, as shown in Table 9.

Table 9. The Weight of Each Regressor on the Dependent Variable (Performance as measured by ROE)

\begin{tabular}{|c|c|c|c|c|c|c|c|c|c|c|c|}
\hline \multicolumn{3}{|c|}{ Sources of Scanning (impersonal) } & \multicolumn{3}{|c|}{ Interest in Scanning } & \multicolumn{3}{|c|}{ Scanning Frequency } & \multicolumn{3}{|c|}{ Obstacles of Scanning } \\
\hline & $\mathrm{B}$ & P-Value & & $\mathrm{B}$ & P-Value & & $\mathrm{B}$ & P-Value & & B & P-Value \\
\hline Con & 3.579 & .000 & Con & 2.248 & 0.000 & Con & 3.690 & .000 & Con & 3.454 & .000 \\
\hline $\mathrm{X} 28$ & 0.000 & .240 & $\mathrm{X} 2$ & 0.034 & .243 & $\mathrm{X} 10$ & 0.000 & .586 & $\mathrm{X} 58$ & 0.0147 & .804 \\
\hline $\mathrm{X} 29$ & 0.000 & .364 & $\mathrm{X} 3$ & .229 & .002 & $\mathrm{X} 11$ & 0.001 & .074 & X59 & -0.089 & .149 \\
\hline $\mathrm{X} 30$ & 0.000 & .163 & $\mathrm{X} 4$ & 0.053 & .459 & $\mathrm{X} 12$ & -5.019 & .957 & X60 & -0.091 & .198 \\
\hline X31 & 0.000 & .485 & X5 & 0.075 & .250 & X13 & 0.000 & .882 & X61 & .165 & .018 \\
\hline X32 & 0.001 & .020 & X6 & .165 & .009 & X14 & 0.000 & .181 & X62 & -0.043 & .506 \\
\hline X33 & -1.646 & .983 & X7 & -0.026 & .702 & X15 & -0.000 & .637 & X63 & .129 & .068 \\
\hline X34 & -0.000 & .308 & $\mathrm{X} 8$ & -0.088 & .175 & X16 & 0.000 & .441 & X64 & 0.020 & .757 \\
\hline X35 & 0.000 & .260 & & & & & & & & & \\
\hline X36 & 0.000 & .561 & & & & & & & & & \\
\hline X37 & -0.000 & .890 & & & & & & & & & \\
\hline X38 & 0.000 & .798 & & & & & & & & & \\
\hline
\end{tabular}




\section{Notes: -}

$>\quad$ Interest in Scanning from X2 = customer scanning, (X3) = competition scanning, (X4) = sources of resources scanning, (X5) $=$ political and legal scanning, $(\mathrm{X} 6)=$ economical scanning, $(\mathrm{X} 7)=$ technological scanning , and $(\mathrm{X} 8)=$ socio-cultural scanning.

$>\quad$ Obstacles of Scanning from $(X 58)=$ government bureaucracy, (X59) $=$ information in a different language, (X60) $=$ inadequate management education/training, $(X 61)=$ uncertainty regarding government long-term policies, $(X 62)=$ absence of data sources, $(X 63)=$ the quality of available information, and (X64) =decentralization of decision making.

$>\quad$ Impersonal Sources from $(\mathrm{X} 28)=$ trade journals, $(\mathrm{X} 29)=$ reports of trade and professional associations, (X30) $=$ scientific journals, (X31) = Media (TV and regular press), (X32) = Governmental reports, (X33) = addressed speeches by management members of rivals, $(\mathrm{X} 34)$ =non-governmental community organizations, $(\mathrm{X} 35)=$ analyst reports about the market, $(\mathrm{X} 36)=$ patent or copy right records, $(\mathrm{X} 37)=$ court records related to your market, and $(\mathrm{X} 38)=$ using market research firms.

$>\quad$ Con $=$ Constant.

$>\quad y=\propto+\beta_{1} x_{1}+\beta_{2} x_{2}+\beta_{3} x_{3}+\ldots \ldots .+\beta_{n} x_{n}+\in$ (Cooper and Emory, 1995, p. 499).

Where: - $y=$ The dependent variable (performance as measured by ROE);

$\propto=$ The value of $y$ if all X's (from $x_{1} \rightarrow x_{n}$ ) equal zero (constant value);

$\beta_{X}=$ The general liner model slopes of $x_{i}$, or the response. The $\beta$ represent the regression coefficient associated with each $X_{i}$;

$X_{i}=$ The independent variables (e.g. 4 constructs); and

$\in \stackrel{i}{=}$ Model' error, $\in$ is assumed to be zero.

As shown in Table (8) and based on Multiple Regression (MR) results, there are significant relationships between performance as measured by profit margin (PM) and interest in scanning, scanning frequency, sources of scanning (personal), and sources of scanning (impersonal), as $p<0$. 05. Consequently, the alternative hypotheses $\left(\boldsymbol{H}_{2 A}\right),\left(\boldsymbol{H}_{3 A}\right),\left(\boldsymbol{H}_{5 A}\right)$, and $\left(\boldsymbol{H}_{6_{A}}\right)$ are supported. However, no relationships are existed between performance as measured by PM and demographics, kinds of scanning, and obstacles of scanning as $p>0$. 05i.e.

0.196, 0.452, and 0.092 respectively. Therefore, the alternative hypotheses $\left(\boldsymbol{H}_{1_{A}}\right),\left(\boldsymbol{H}_{4 A}\right)$, and $\left(\boldsymbol{H}_{7 A}\right)$ are not supported. The most remarkable things are:

- Interest in scanning, scanning frequency, sources of scanning (personal), and sources of scanning (impersonal), affect the performance of profit oriented businesses.

- The process of data entry did not affected by the process of entry order, as Durbin-Watson test reported values $>1.4$ for all dependent variables, as shown in Table (10).

- The explanation powers of these models are weak, as "R square" and "adjusted R" values indicate. More specifically, these four IVs \{i.e. interest in scanning, scanning frequency, sources of scanning (impersonal), and sources of scanning (personal) $\}$ are responsible only for $0.117,0.079,0.166$, and 0.156 respectively, of the behavior of the DV (performance as measured by PM.However, if the adjusted R square has been taken into consideration, the magnitude of IVs shrink tosmall proportions, as shown in Table (10).

Table 10. Multiple Regressions between Scanning Concepts and Performance (Measured by PM)

\begin{tabular}{|c|c|c|c|c|c|c|}
\hline & $\mathbf{F}$ & P-value & $\mathbf{R}$ & R Square & $\begin{array}{l}\text { Adjusted R } \\
\text { Square }\end{array}$ & Durbin-Watson \\
\hline Demographics & 1.481 & 0.196 & 0.158 & .025 & .008 & 1.615 \\
\hline Interest in Scanning & 5.351 & $0.000 * * *$ & 0.341 & .117 & .095 & 1.652 \\
\hline Scanning Frequency & 3.480 & $0.001 * * *$ & 0.281 & .079 & .056 & 1.627 \\
\hline Kinds of Scanning & .961 & 0.452 & 0.141 & .020 & -.001 & 1.565 \\
\hline Sources of Scanning (impersonal) & 5.071 & $0.000 * * *$ & 0.407 & .166 & .133 & 1.466 \\
\hline Sources of Scanning (personal) & 3.157 & $0.000 * * *$ & 0.395 & .156 & .107 & 1.663 \\
\hline Obstacles of Scanning & 1.772 & 0.092 & 0.204 & .042 & .018 & 1.588 \\
\hline
\end{tabular}

However, not all IVs have significant relationship with the performance as measured by PM. More specifically, scanning scientific journals (X30), governmental reports (X32), and addressed speeches by management members of rivals (X33) are the only three IVs within the construct of impersonal sources of scanning from X28 to $\mathrm{X} 38$ ) that have significant relationships with performance as measured by PM, as $p=0.000,0.026$ and 0.008 , as shown in Table (11).Competition scanning (X3), and socio-cultural scanning (X8) are the only two IVs (within 
the construct of interest of scanning from $\mathrm{X} 2$ to $\mathrm{X} 8$ ) that have significant relationships with performance as measured PM, as $p=0.013$, and 0.015 . Customer scanning(X10) is the only IV (within the construct of frequency of scanning from X10 to X16)that has significant relationship with performance as measured by PM, as $p=$ $0.001<0.05$. Finally, sales force $(\mathrm{X} 41)$,personnel hired from competitors (X43), and channel of distribution (X44) are the only IVs (within personal sources of scanning from X41 to X55) that have significant relationships with performance as measured by PM, as $p=0.109,0.00$, and $0.020<0.05$.

Table11.The Weight of Each Regressor on the Dependent Variable (Performance as measured by PM)

\begin{tabular}{|c|c|c|c|c|c|c|c|c|c|c|c|}
\hline \multicolumn{3}{|c|}{ Source of Scanning (impersonal) } & \multicolumn{3}{|c|}{ Interest in Scanning } & \multicolumn{3}{|c|}{ Scanning Frequency } & \multicolumn{3}{|c|}{ Source of Scanning (personal) } \\
\hline & B & P-Value & & B & P-Value & & B & P-Value & & B & P-Value \\
\hline Con & 3.469 & .000 & Con & 2.028 & .000 & Con & 3.554 & .000 & Con & 3.573 & .000 \\
\hline $\mathrm{X} 29$ & -0.001 & .107 & $\mathbf{X 3}$ & .228 & .013 & $\mathrm{X} 11$ & 0.000 & .397 & $\mathrm{X} 42$ & -0.001 & .053 \\
\hline $\mathbf{X 3 0}$ & 0.003 & .000 & $\mathrm{X} 4$ & .156 & .081 & $\mathrm{X} 12$ & -7.214 & .948 & $\mathrm{X} 43$ & 0.003 & .000 \\
\hline $\mathrm{X} 31$ & 0.000 & .651 & $\mathrm{X} 5$ & 0.077 & .340 & X13 & 0.000 & .292 & X44 & -0.002 & .022 \\
\hline X32 & 0.001 & .026 & X6 & 0.059 & .444 & X14 & 0.000 & .736 & X45 & -0.001 & .091 \\
\hline X33 & -0.002 & .008 & X7 & 0.098 & .250 & X15 & -0.000 & .440 & X46 & 0.001 & .020 \\
\hline X34 & 0.001 & .124 & X8 & -.198 & .015 & X16 & -0.000 & .680 & X47 & -0.001 & .115 \\
\hline X35 & 0.000 & .344 & & & & & & & X48 & 0.001 & .067 \\
\hline X36 & 0.001 & .174 & & & & & & & X49 & -0.000 & .570 \\
\hline X37 & -3.257 & .997 & & & & & & & X50 & -0.000 & .492 \\
\hline \multirow[t]{5}{*}{ X38 } & -0.001 & .385 & & & & & & & X51 & 0.001 & .149 \\
\hline & & & & & & & & & X53 & -0.000 & .473 \\
\hline & & & & & & & & & X54 & 0.001 & .059 \\
\hline & & & & & & & & & X55 & 0.000 & .651 \\
\hline & & & & & & & & & X56 & -0.000 & .789 \\
\hline
\end{tabular}

Notes: -

$>\quad$ Interest in Scanningfrom X2 =customer scanning, $(\mathrm{X} 3)=$ competition scanning, $(\mathrm{X} 4)=$ sources of resources scanning, $(\mathrm{X} 5)=$ political and legal scanning, $(\mathrm{X} 6)=$ economical scanning, $(\mathrm{X} 7)=$ technological scanning, and $(\mathrm{X} 8)=$ socio-cultural scanning.

$>\quad$ Impersonal Sources from $(X 28)=$ trade journals, $(X 29)=$ reports of trade and professional associations, $(X 30)=$ scientific journals, $(X 31)=$ media (TV and regular press), (X32) = governmental reports, $(X 33)=$ addressed speeches by management members of rivals, $(\mathrm{X} 34)=$ non-governmental community organizations, $(\mathrm{X} 35)=$ analyst reports about the market, $(\mathrm{X} 36)=$ patent or copy right records, $(\mathrm{X} 37)=$ court records related to your market, and $(\mathrm{X} 38)=$ using market research firms.

$>\quad$ Personal Sources from $(X 41)=$ sales force, $(X 42)=$ engineering staff, $(X 43)=$ personnel hired from competitors, $(X 44)=$ channel of distribution, $(\mathrm{X} 45)=$ suppliers, $(\mathrm{X} 46)=$ analyzing customers feedbacks, $(\mathrm{X} 47)=$ advertising agencies, $(\mathrm{X} 48)=$ the most-valued customers of your firm, $(\mathrm{X} 49)=$ prospects opinions, $(\mathrm{X} 50)=$ firm's referrals, $(X 51)=$ professional meetings inside, $(X 52)=$ business meetings with current competitors themselves, $(\mathrm{X} 53)=$ analyzing the security price, $(\mathrm{X} 54)=$ analyzing the security prices of rivals, (X55) = analyzing the success ratio in trade associations, and (X56) = conducting company-sponsored surveys.

$>\quad$ Frequency of Scanning from $(X 10)=$ customer scanning, $(X 11)=$ competition scanning, $(X 12)=$ sources of resources scanning, $(X 13)=$ political and legal scanning,$(\mathrm{X} 14)=$ economical scanning, $(\mathrm{X} 15)=$ technological scanning, and $(\mathrm{X} 16)=$ socio-cultural Scanning.

$>\quad$ Con $=$ Constant

Finally, UAE businesses are conducting regular scanning more often than irregular scanning. And proactive scanning is conducted more frequently than reactive one. Therefore, the hypotheses $\left(\boldsymbol{H}_{8}\right)$ and $\left(\boldsymbol{H}_{9}\right)$ are supported. Moreover, hoc scanning is conducted more frequently compared with primitive scanning, as $p$ value, mean, and sum in Table (12) show. Therefore, $\left(\boldsymbol{H}_{9}\right)$ is supported. These results contradict with Jain's study(1984) in which only 14 of the 186 companies (about $8 \%$ ) had a proactive scanning system in use and nearly 70 percent used either the primitive or the ad hoc models, as shown in Table (13). 
Table 12.Wilcoxon Signed Ranks Test (WSRT)

\begin{tabular}{|c|c|c|c|c|c|c|}
\hline & \multicolumn{2}{|c|}{ Wilcoxon Test } & \multirow{2}{*}{$\begin{array}{l}\text { Mean } \\
\text { X21 }\end{array}$} & \multicolumn{3}{|c|}{ Sum } \\
\hline & $Z$ value & $\boldsymbol{P}$ & & $\mathbf{X} 22$ & $\mathbf{X} 21$ & $\mathbf{X} 22$ \\
\hline Regular (X21) and Irregular (X22) Scanning & -2.287 & $0.022 \mathrm{R}$ & 3.801 & 3.646 & 1110 & 1061 \\
\hline \multirow[t]{2}{*}{ Reactive (X23) and Proactive (X24) Scanning } & -3.200 & $0.001 \mathrm{R}$ & $\mathbf{X} 23$ & $\mathbf{X} 24$ & $\mathbf{X} 23$ & $\mathbf{X} 24$ \\
\hline & & & 3.448 & 3.6233 & 1007 & 1058 \\
\hline \multirow[t]{2}{*}{ Primitive (X25) and Hoc scanning (X26) Scanning } & -1.759 & $0.000 \mathrm{R}$ & $\mathbf{X} 25$ & $\mathbf{X} 26$ & $\mathbf{X} 25$ & X26 \\
\hline & & & 3.390 & 3.434 & 990 & 1004 \\
\hline
\end{tabular}

Note: -

$>\quad \mathbf{R}=$ Rejecting the null hypothesis that; "the median of the population difference $\left(\mathrm{X}_{i}-Y_{i}\right)=D_{i}$ is zero", as $p \leq 0.05$;

$>\quad$ Mean ...meansadding up all the values and divide by the number of values;

$>\quad$ Sum is the total score of that variable within the sample.

$>\quad$ Primitive scanning is the kind of scanning that accept all antecedences and consequences imposed by the external environment as an inevitable and dealing with these information by unsystematic, and unintentionally way (Jain (1984).

$>$ Hoc scanning is the kind of scanning that enables from watching a few areas that need to be watched carefully.

$>\quad$ Reactive scanning is the kind of scanning that follows the footsteps of the leader in the market by an unplanned, and unstructured way.

$>\quad$ Proactive scanning is a panned and structured process aims at intentionally monitoring specific areas considered crucial for reaping competitive advantages. The objective of the proactive scanning system is to predict the environment for a desired future (Subramanian et al., 1993).

Table 13. Kinds of scanning percentages

\begin{tabular}{|c|c|c|c|c|c|c|}
\hline \multirow[t]{2}{*}{ Kinds of Scanning } & \multicolumn{6}{|l|}{ Percent } \\
\hline & Strongly Agree & $\begin{array}{l}\text { Inclined to } \\
\text { Agree }\end{array}$ & $\begin{array}{l}\text { Undecided; } \\
\text { Don't know }\end{array}$ & $\begin{array}{l}\text { Inclined to } \\
\text { Disagree }\end{array}$ & $\begin{array}{l}\text { Strongly } \\
\text { Disagree }\end{array}$ & $\begin{array}{l}\text { Missed } \\
\text { Value } \\
\end{array}$ \\
\hline - Irregular & 22.9 & 36.6 & 25.7 & 10.6 & 3.8 & .3 \\
\hline Reactive & 17.5 & 34.9 & 27.7 & 14.7 & 5.1 & 0 \\
\hline Primitive & 15.4 & 33.2 & 32.9 & 12.0 & 6.5 & 0 \\
\hline Hoc scanning & 15.4 & 28.4 & 32.2 & 14.4 & 8.9 & .3 \\
\hline
\end{tabular}

\subsection{Conclusion and Recommendations}

In the current research, evidences from a booming middle east economy (UAE)have proved the tie amongst performance (as measured by ROE and PM) and interest in scanning, scanning frequency, sources of scanning (impersonal and personal), and obstacles of scanning. However, the explanation powers of multiple regression models are weak, other regressors rather than those used in the current study are recommended to be added.Consequently, other scholars are invited to explore other variables. Moreover, UAE businesses are conducting regular, proactive, and hoc scanning more often than irregular, reactive, and primitive scanning.

As the current study adopted ROE and PM as performance measuring tools, other scholars are invited for testing some other tools in a middle east context. Number of added or deleted products and services in the period followed the scanning process was used by Elenkov (1997) to measure the performance. It is worth copying that approach in a middle east context. Also, some other scholars (i.e. Subramanian et al., 1993) used the profitability (measured by ROA) and growth in sales.

\section{References}

Adegbite, O. (1986). Planning in Nigerian Business.Long Range Planning, 19(4), 98-103. https://doi.org/10.1016/0024-6301(86)90276-1

Aguilar, F. J. (1967). Scanning the Business Environment. New York:Macmillan.

Albright, K. S. (2004). Environmental Scanning: Radar for Organizational Success. Information Management Journal, 38-45.

Anastos, D., Bedos, A., \& Seaman, B. (1980).The Development of Modern Management Practices in Saudi Arabia. Columbia Journal of World Business, 15(2), 81-92. 
Asheghian, P., \& Ebrahimi, P. (1990).International Business. New York: Harper Collins.

Ashour, S. (1993).Statistical Analysis and Presentation by Using SPSS. Cairo Statistical Institute, Cairo University Press, Egypt.

Auster, E., \& Choo, C. W. (1994).How Senior Managers Acquire and Use Information in Environmental Scanning. Journal of the American Society for Information Science, 44(4), 194-203.https://doi.org/10.1016/0306-4573(94)90073-6

Boulton, W. R., Lindsay, W. M., Franklin, S. G., \& Rue, L. W. (1982).Strategic Planning: Determining the Impact of Environmental Characteristics and Uncertainty. Academy of Management Journal, 25(3), 500-509. https://doi.org/10.2307/256076

Boyd, B. K., \& Fulk, J. (1996).Executive Practices and Perceived Uncertainty: A Multidimensional Model. Journal of Management, 22(1), 1-21.https://doi.org/10.1177/014920639602200101

Bryman, A., \& Cramer, D., (1999). Quantitative Data analysis with SPSS Release 8 for Windows: A Guide for Social Scientists. London: Routledge. https://doi.org/10.4324/9780203459621

Chan, Y., Huff, S., \& Copeland, D. G. (1998). Assessing Realized Information Systems Strategy. Journal of Strategic Information Systems, 6, 273-298.https://doi.org/10.1016/S0963-8687(97)00005-X

Cheng.(2014). The Strategic Planning of SMEs in Malaysia. International Journal of Business and Society, 15(3), 437-446.

Cooper, D.,\& Emory, C. W. (1995).Business Research Methods. Richard D. Irwin, INC., USA.

Costa, J., \& Teare, R.(2000).Developing an environmental scanning process in the hotel sector. International Journal of Contemporary Hospitality Management, 156-169.https://doi.org/10.1108/09596110010320652

Daft, R. L., \& Weick, K. E.(1984).Toward a Model of Organizations as Interpretation Systems. Academy of Management Review, 9(2), 284-295.

Daft, R. L; Sormunen, J; and Parks, D. (1988).Chief Executive Scanning, Environmental Characteristics, and Company Performance: An Empirical Study. Strategic Management Journal, 9(3), 123-139.https://doi.org/10.1002/smj.4250090204

Dill, W. R. (1958). Environment as an Influence on Managerial Autonomy. Administrative Science Quarterly, 3(1), 409-443. https://doi.org/10.2307/2390794

Douglas, B. (1994). Organizing for Environmental Scanning: Orthocloxies and Reformations. Journal of Marketing Management, 10, 703-723.https://doi.org/10.1080/0267257X.1994.9964317

Ebrahimi, B. P. (2000). Perceived Strategic Uncertainty and Environmental Scanning Behavior of Hong Kong Chinese Executives. Journal of Business Research, 67-78.https://doi.org/10.1016/S0148-2963(98)00120-9

Elenkov, D. S. (1997).Environmental Scanning Systems and Performance: An Empirical Study of Russian Companies. Journal of Management 111-125.https://doi.org/10.1108/02621719710164283

El-Ragal, A. (2001).Building DSS Using Knowledge Discovery in Database Techniques: Applied to Admissions and Registration Functions. Unpublished PhD Thesis, Business School, University of Plymouth, UK.

Fahey, L.,\& King, W.R. (1977).Environmental Scanning for Corporate Planning. Business Horizons, 61-71.https://doi.org/10.1016/0007-6813(77)90010-6

Farh, J., Hoffman, R., \& Hegarty, W. (1984).Assessing Environmental Scanning at the Subunit Level: A Multitrait-Multimethod Analysis. Decision $\quad$ Science, 197-220.https://doi.org/10.1111/j.1540-5915.1984.tb01209.x

Flores, F. (1972).The Applicability of American Management Practices to Developing Countries: A Case Study of the Philippines. Management International Review, 12(1), 83-89.

Foster, J. (2001). Data Analysis Using SPSS for Windows(2nd eds.).London: Sage Ltd.

Fubara, B. A. (1986). Corporate Planning in Nigeria. Long Range Planning, 19(2), 125-132.https://doi.org/10.1016/0024-6301(86)90229-3

Ghiselli, E., Campbell, J.,\& Zedeck, S. (1981).Measurement Theory for the Behavioral Sciences. W. H. Freeman, 
San Francisco, USA.

Grant, R. M. (1998). Contemporary Strategy Analysis(2nd ed.).Blackwell Publishers, Oxford.

Hagen, A. F., \& Amin, S. G. (1995).Corporate Executives and Environmental Scanning Activities: An Empirical Investigation. SAM Advanced Management Journal, 60(2), 41-48.

Hambrick, D. C. (1982). Environmental Scanning and Organizational Strategy. Strategic Management Journal, 3 , 159-174.https://doi.org/10.1002/smj.4250030207

Hambrick, D. C. (1981). Specialization of Environmental Scanning Activities Among Upper Level Executives. Journal of Management Studies, 18, 299-320.https://doi.org/10.1111/j.1467-6486.1981.tb00104.x

Hambrick, D. C., \& Mason, P. A. (1984). Upper Echelons: the Organization as A Reflection of Its Top Managers. Academy of Management Review, 9, 193-206.

Hax, A. C., \& Majluf, N. S. (1984).Strategic Management: An Integrative Perspective. Prentice-Hall: Englewood Cliffs.

Hidayat, G. (2015).Effects of Environmental Factors on Corporate Strategy and Performance of Manufacturing Industries. Journal of Industrial Engineering and Management, 8(3), 233-236.https://doi.org/10.3926/jiem.1326

Hofer, C. W., \& Schendel, D. (1978.Strategy Formulation: Analytical Concepts. St. Paul, West Publishing, MN.

Jain, S.C. (1984). Environmental Scanning in US Corporations. Long Range Planning, 17(2), 117-128.https://doi.org/10.1016/0024-6301(84)90143-2

Kamangar. (2013). Developing Strategic Thinking. Journal of Basic and Applied Scientific Research, 3(6), 546-552.

Keil, M., Mann, J., \& Rai, A. (2000).Why Software Projects Escalate: An Empirical Analysis and Test of Four Theoretical Models. MIS Quarterly, 24(4), 631-664.https://doi.org/10.2307/3250950

Kim, L., \& Lim, Y. (1988).Environment, Generic Strategies, and Performance in A Rapidly Developing Country: A Taxonomic Approach. Academy of Management Journal, 31(4), 802-827.https://doi.org/10.2307/256339

Kline, P. (1997). An Easy Guide for Factor Analysis. London: Routledge.

Lawrence, P.R.,\&Lorsch, J. W.(1967).Organizations and Environment. Irwin, Homewood, IL.

Lotayif, A. M. M. S. (2005).Modes and Different Marketing Strategies Models", In \{Kiefer Lee and Steve Carter. Global Marketing Management,176-180.

Lotayif, M. (2003a).A theoretical model for matching entry modes with defensive marketing strategies. Journal of American Academy of Business, 2(2), 460-466.

Lotayif, M. (2003b). Dependency Relationships with Defensive Marketing Strategies; Evidence from the Egyptian Banking Sector. presented at the first International Conference on Information and Management Science (IMS2002); in Xi'An, China in the period from May 27th - 31st, paper No. 56.

Lotayif, M. (2004a).Factors that Affect the Selection of Defensive Marketing Strategies: Evidence from the Egyptian Banking Sector. The Journal of American Academy of Business, 4(1 \&2), 152-158.

Lotayif, M. (2004b). GATS Impacts on Entry Modes and Defensive Marketing Strategies in the Egyptian Banking Sector. Published PhD Thesis, Department of International Business, Plymouth Business School, University of Plymouth, UK.

Lotayif, M. (2014).Causality Relationship for Selection Variables of Brand Creation and Brand Acquisition as Expansion Strategies: Evidence from Egypt. The Journal of American Academy of Business, 19(2), 287-285.

Lotayif, M. (2015a).University Industry (U-I) Relationship: Evidence from an Egyptian University. International Journal of Business and Management (IJBM), 10(4), 113-122. https://doi.org/10.5539/ijbm.v10n4p113

Lotayif, M. (2015b). The Components of Marketing Strategies Making (MSM) and the Relationships with Strategy Antecedents and Consequences: Evidences from Egypt. The Business Review, Cambridge (BRC), 2, 27-136.

Lotayif, M. (2016).Selection Factors of Market Segments and Porter's Generic Marketing Strategies: Evidence from an Emerging GCC Market. International Journal of Business and Management (IJBM), 11(1), 199-215. https://doi.org/10.5539/ijbm.v11n1p199 
Lotayif, M. (2017a). Causality Relationships between Main Branding Variables and International Marketing Strategy: Evidence from MNCs in GCC Markets. International Journal of Business and Management (IJBM), 12(1), 140-158. https://doi.org/10.5539/ijbm.v12n8p140

Lotayif, M. (2017b). Covering International Marketing Influences on Firm International Performance: Evidences from GCC. International Journal of Business and Management, 12(3), 274-297.https://doi.org/10.5539/ijbm.v12n8p274

Lotayif, M., \& El-Ragal, A. (2004).Investigating and Modelling GATS Impacts on the Developing Countries: Evidence from the Egyptian Banking Sector. The Journal of American Academy of Business, 4(1\&2), 496-502.

Malhotra, N. K. (1993). Marketing Research an Applied Orientation. New Jersey: Prentice-Hall, Inc.

Manuel, Y. (2005). Environment Scanning for Strategic Information: Content Analysis from Malaysia. The Journal of American Academy of Business, 2, 324-331.

Miles, R. E. (1982). Coffin Nails and Corporate Strategies. Prentice-Hall, Englewood Cliffs, NJ.

Milliken, F.J.,\&Lant, T. K. (1991).The Effects of an Organization's Recent Performance History on Strategic Persistence and Change: The Role of Managerial Interpretations. In Shrivastava, P., Huff, A. and Dutton, J. (Eds.), Advances in Strategic Management (Vol. 7, pp. 129-156).

Mrema, E. L.(1987). Strategic Planning in Tanzania. Long Range Planning, 20(3), 105-110. https://doi.org/10.1016/0024-6301(87)90078-1

Nunnally, J. C. (1978). Psychometric Theory (2nd eds.). New York: McGraw-Hill

Nwachukwu, J. C. (1985). Quality Control Practice in Developing Countries: the Case of Nigeria. Management International Review, 25(4), 73-78.

Ortuzar, J. D., \& Willumsen, L. G. (1994). Modelling Transport. New York: John Wiley and Sons Ltd.

O'Shaughnessy, N. J. (1985). Strategy and US Cultural Bias. European Journal of Marketing, 19(4), 23-32.https://doi.org/10.1108/EUM0000000004743

Pearce, J. A., Robbins, D. K.,\& Robinson, R. B. (1987).The Impact of Grand Strategy and Planning Formality on Financial Performance. Strategic Management Journal, 14(4), 134. https://doi.org/10.1002/smj.4250080204

Pfeffer, J., \& Salancik, F. R.(1978).The External Control of Organizations. New York:Harper and Row.

Porter, M. E. (1980). Competitive Strategy: Techniques For Analyzing Industries and Competitors. New York: The Free Press.

Preble, J. F., Rau, P. A., \& Reichel, A.(1988).The Environmental Scanning Practices of U.S. Multinationals in The Late 1980s. Management International Review, 28(4), 4-14.

Ramunujam, V., Venkatraman, N., \& Camillus, J. C.(1986).Multi-Objective Assessment of Effectiveness of Strategic Planning: A Discriminant Analysis Approach. Academy of Management Journal, 347-372. https://doi.org/10.2307/256192

Ravichandran, T., \& Rai, A. (2000).Quality Management in Systems Development: An Organizational System Perspective. MIS Quarterly, 24(3), 381-415. https://doi.org/10.2307/3250967

Rust, J., \& Golombok, S. (1999). Modern Psychometrics (2nd ed.). London: Routledge.

Saravanan, R.,\&Rao, K. S. P. (2007).Measurement of Service Quality from the Customer's Perspective - An Empirical Study.Total Quality Management, 18(4), 435-449.https://doi.org/10.1080/14783360701231872

Sawyerr, O. O. (1993). Environmental Uncertainty and Environmental Scanning Activities of Nigerian Manufacturing Executives: A Comparative Analysis.Strategic Management Journal,14(4), 287-299. https://doi.org/10.1002/smj.4250140405

Sawyerr, O. O., Ebrahimi, B. P.,\& Thibodeaux, M. S. (2000). Executive Environmental Scanning, Information Source Utilisation, and Firm Performance: the Case of Nigeria. Journal of Applied Management Studies, 9(1), 95-117. https://doi.org/10.1080/713674356

Sawyerr, O. P. (1985). Long Range Strategic Planning in Manufacturing Firms in Rivers State. Unpublished Masters Thesis, Department of Management Science. University of Port Harcourt.

Siffin, W. J.(1976). Two Decades of Public Administration in Developing Countries. Public Administration 
Review, 36(1), 61-71. https://doi.org/10.2307/974742

Smith, K. G., Grim, C. M., Gannon, M. J.,\& Chen, M. (1991).Organizational Information Processing, Competitive Responses, and Performance in the US Domestic Airline Industry. Academy of Management Journal,34, 60-85. https://doi.org/10.2307/256302

Snyder, N. (1981). Environmental Volatility, Scanning Intensity, and Organizational Performance. Journal of Contemporary Business, 10, 5-17.

Stat graphics.(2000). The Manual of Stat Graphics.

Stodnick, M., \& Pamela, R. (2008).Using SERVQUAL to Measure the Quality of the Classroom Experience. Decision Sciences Journal of Innovative Education, 6(1), 115-134. https://doi.org/10.1111/j.1540-4609.2007.00162.x

Subramanian, R.,Fernandes, N.,\& Harper, E. (1993).Environmental Scanning In U.S. Companies: Their Nature And Their Relationship To Performance. Management International Review, 33(3), 271-287.

Teo, T., \& King, W. (1996).Assessing The Impact of Integrating Business Planning and IS Planning. Information and Management, 30, 309-321. https://doi.org/10.1016/S0378-7206(96)01076-2

Toit, M. (2005).Using Environmental Scanning to Collect Strategic Information.International Journal of Information Management, 36, 16-24.

Van de Ven, A., \& Joyce, W. F. (1981).Perspectives in Organization Design and Behavior. New York: John Wiley and Sons.

Wheelen, T. L., \& Hunger, J. D. (1992).Strategic Management and Business Policies. New York: Addison-Wesley.

Wonnacott, T. H., \& Wonnacott, R. J. (1990).Introductory Statistics for Business and Economics. John Wiley and Sons Inc.

Woo, C. Y., \& Willard,G. E. (1983). Performance Representation in Business Policy Research: Discussion and Recommendations. Presentation at the Academy of Management Meetings.

Zahra, S. A.(1987). Corporate Strategic Type, Environmental Perceptions, Managerial Philosophies, And Goals: An Empirical Study. Akron Business and Economic Review, 18(2), 64-77.

Zajac, E. J., \& Shortell, S. M.(1989).Changing Generic Strategies: Likelihood, Direction, and Performance Implications. Strategic Management Journal, 10, 413-430. https://doi.org/10.1002/smj.4250100503

\section{Appendix (A)}

First: About you:-

\section{Demographics}

Position:-

Age:-

Educational level:-

\begin{tabular}{|l|l|l|l|}
\hline Between 25- 35 years & & Over 55- 65 years & \\
\hline Over 35: 45 years & & Over 65 years & \\
\hline Over 45- 55 years & & & \\
\hline
\end{tabular}

\begin{tabular}{|l|l|l|l|}
\hline Sub-University degree & Master degree & \\
\hline University degree & & Ph. D.degree & \\
\hline
\end{tabular}

Years of Experience in this position and similar positions:-

Second: About your firm

Number of years your firm has been in business:-

Number of Employees:-

\begin{tabular}{|l|l|l|l|}
\hline Less than100 & & From 1001-10000 & \\
\hline
\end{tabular}




\begin{tabular}{|l|l|l|l|}
\hline From 101-1000 & & More than 10000 & \\
\hline
\end{tabular}

\section{Environmental Scanning interest}

(1) Do you have interest in environmental scanning? (X1)
Yes
No
(1) Customer scanning means updating your recodes by the needs and desires;
(2) Competition scanning means updating your records by the competitive advantages of both the new comers and old counterparts in the markets;
(3) Sources of Resources scanning means updating your suppliers' list through adding and deleting based on the analysis of each case;
(4) Political and Legal scanning means analyzing government's practices and trends;
(5) Economical scanning means updating your records by the changes in tax policy, inflation rate, currency exchange rate, unemployment rate,

\begin{tabular}{|l|l|l|l|l|l|}
\hline Scanning Sectors (to measure the interest) & $\begin{array}{l}\text { Very } \\
\text { low } \\
\text { (1) }\end{array}$ & $\begin{array}{l}\text { Low } \\
\text { (2) }\end{array}$ & $\begin{array}{l}\text { Medium } \\
\text { (3) }\end{array}$ & $\begin{array}{l}\text { High } \\
\text { (4) }\end{array}$ & $\begin{array}{l}\text { Very } \\
\text { high } \\
\text { (5) }\end{array}$ \\
\hline $\begin{array}{l}\text { (2) The degree to which you make Customer Scanning a point of your } \\
\text { interest to keep abreast of information related to it (X2) }\end{array}$ & & & \\
\hline $\begin{array}{l}\text { (3) The degree to which you make Competition Scanning a point of } \\
\text { your interest to keep abreast of information related to it (X3) }\end{array}$ & & & & \\
\hline $\begin{array}{l}\text { (4) The degree to which you make Sources of Resources Scanning a } \\
\text { point of your interest to keep abreast of information related to it (X4) }\end{array}$ & & & & \\
\hline $\begin{array}{l}\text { (5) The degree to which you make Political and Legal Scanning a point } \\
\text { of your interest to keep abreast of information related to it (X5) }\end{array}$ & & & & \\
\hline $\begin{array}{l}\text { (6) The degree to which you make Economical Scanning a point of } \\
\text { your interest to keep abreast of information related to it (X6) }\end{array}$ & & & & \\
\hline $\begin{array}{l}\text { (7) The degree to which you make Technological Scanning a point of } \\
\text { your interest to keep abreast of information related to it (X7) }\end{array}$ & & & & \\
\hline $\begin{array}{l}\text { (8) The degree to which you make Socio-Cultural Scanning a point of } \\
\text { your interest to keep abreast of information related to it (X8) }\end{array}$ & & & & \\
\hline
\end{tabular}

\section{Environmental Scanning Frequency}

\begin{tabular}{|l|l|l|l|l|l|l|}
\hline Scanning Sectors (to measure the frequency) & $\begin{array}{l}\text { Never } \\
(0)\end{array}$ & $\begin{array}{l}\text { Yearly } \\
(1)\end{array}$ & $\begin{array}{l}\text { Quarter } \\
\text { ly (4) }\end{array}$ & $\begin{array}{l}\text { Mont } \\
\text { hly } \\
(12)\end{array}$ & $\begin{array}{l}\text { Wee } \\
\text { kly } \\
(52)\end{array}$ & $\begin{array}{l}\text { Daily } \\
(365)\end{array}$ \\
\hline (1) How often you execute Customer scanning (X10) & & & & & & \\
\hline (2) How often you execute Competition (X11) & & & & & & \\
\hline (3) How often you execute Sources of Resources scanning (X12) & & & & & & \\
\hline (4) How often you execute Political and Legalscanning(X13) & & & & & & \\
\hline (5) How often you execute Economical scanning(X14) & & & & & & \\
\hline (6) How often you execute Technological scanning (X15) & & & & & & \\
\hline (7) How often you execute Socio-Cultural scanning (X16) & & & & & & \\
\hline
\end{tabular}

\section{Measuring the Performance}




\begin{tabular}{|l|l|l|l|l|l|}
\hline Measuring the Performance & $\begin{array}{l}\text { Has } \\
\text { Become } \\
\text { Poorer } \\
(1)\end{array}$ & $\begin{array}{l}\text { Slightlypoorer } \\
(2)\end{array}$ & $\begin{array}{l}\text { Equal } \\
(3)\end{array}$ & $\begin{array}{l}\text { Slightlybetter } \\
(4)\end{array}$ & $\begin{array}{l}\text { Has } \\
\text { Become } \\
\text { Better (5) }\end{array}$ \\
\hline $\begin{array}{l}\text { (3) How to assess your performance over the last } \\
\text { five years relative to that of competitors in Profit } \\
\text { Margin (net income after taxes/sales). (X18) }\end{array}$ & & & & \\
\hline $\begin{array}{l}\text { (4) How to assess your performance over the last } \\
\text { five years relative to that of competitors in Return } \\
\text { On Equity (net income after taxes/total }\end{array}$ & & & & & \\
stockholders' equity) (X19)
\end{tabular}

\section{Kinds of Scanning}

\begin{tabular}{|c|c|c|c|c|c|}
\hline Kinds of Scanning & SA & IA & UD & ID & SD \\
\hline \multicolumn{6}{|l|}{ (1) I do environmental scanning regularly (Regular Scanning) (X21) } \\
\hline \multicolumn{6}{|l|}{$\begin{array}{l}\text { (2) I do environmental scanning whenever there is a need for that (Irregular } \\
\text { Scanning) (X22) }\end{array}$} \\
\hline \multicolumn{6}{|l|}{ (3) I do the scanning to follow the footsteps of rivals (Reactive scanning) (X23) } \\
\hline \multicolumn{6}{|l|}{$\begin{array}{l}\text { (4) I do environmental scanning following the footsteps of market leaders } \\
\text { (Proactive scanning) (X24) }\end{array}$} \\
\hline \multicolumn{6}{|l|}{$\begin{array}{l}\text { (5) I do comprehensive environmental scanning that includes all the related sectors } \\
\text { (Primitive scanning) (X25) }\end{array}$} \\
\hline \multicolumn{6}{|l|}{$\begin{array}{l}\text { (6) I do selective environmental scanning that includes a few sectors ad (Hoc } \\
\text { scanning) (X26) }\end{array}$} \\
\hline Notes: & & & & & \\
\hline
\end{tabular}

\section{Scanning Sources}

\begin{tabular}{|l|l|l|l|l|l|l|}
\hline $\begin{array}{l}\text { How often your collect data depending on the following sources } \\
\text { for your environmental scanning }\end{array}$ & $\begin{array}{l}\text { Never } \\
(0)\end{array}$ & $\begin{array}{l}\text { Yearly } \\
(1)\end{array}$ & $\begin{array}{l}\text { Quart } \\
\text { erly } \\
(4)\end{array}$ & $\begin{array}{l}\text { Mo } \\
\text { nthl } \\
\text { y } \\
(12)\end{array}$ & $\begin{array}{l}\text { Week } \\
\text { ly } \\
(52)\end{array}$ & $\begin{array}{l}\text { Daily } \\
(365)\end{array}$ \\
\hline Impersonal and Secondary Sources & & & & & & \\
\hline (1) Trade Journals (External) (X28) & & & & & & \\
\hline (2) Reports of Trade and Professional Associations (External) (X29) & & & & & & \\
\hline (3) Scientific Journals (External) (X30) & & & & & & \\
\hline (4) Media (TV and regular press) (External) (X31) & & & & & \\
\hline $\begin{array}{l}\text { (5) Governmental reports (all governmental reports e.g. annual } \\
\text { reports from statistical centers and regulatory agencies) (External) } \\
\text { (X32) }\end{array}$ & & & & & & \\
\hline
\end{tabular}


(6) Addressed speeches by management members of rivals (External) (X33)

(7) Non Governmental Community organizations(External) (X34)

(8) Analyst reports about the market (External) (X35)

(9) Patent or copy right records(External) (X36)

(10) Court records related to your market (External) (X37)

(11) Using market research firms (Secondary) External (X38)

(12) Other sources (Please Specify) (X39)

\section{Personal Sources}

(1) Your own sales force (Primary) IN (X41)

(2) Your own engineering staff (Primary) IN(X42)

(3) Personnel hired from competitors (Primary) IN (X43)

(4) Your own distribution channels (Primary) IN (X44)

(5) Investigating the opinions of your own suppliers (Primary) (EX) (X45)

(6) Analyzing customers feedbacks (Internal) (X46)

(6) Your own advertising agencies (Primary) (EX) (X47)

(7) Investigating the opinions of the most-valued customers of your firm (Primary) (EX) (X48)

(8) Investigating prospects opinions (i.e. people shopping around the firm) (Primary) (EX) (X49)

(9) Investigating the opinions of firm's referrals (e.g. real estate brokers, accountants, lawyers, business executives, chamber members and other professionals) (Primary) (EX) (X50)

(10) Conducting professional meetings inside (Primary) (Internal) (X51)

(11) Conducting business meetings with current competitors themselves (Primary) (EX) (X52)

(12) Analyzing your own security prices IN (X53)

(13) Analyzing the security prices of rivals (EX) (X54)

(13) Analyzing the success ratio in trade associations (i.e. backward, forward, and horizontal business integrations) EX (X55)

(14) Conducting company-sponsored surveys (Internal) (X56)

Other sources (Please Specify) (X57)

Notes:

$\mathrm{SA}=$ Strongly Agree, IA = Inclined to Agree, UD = Undecided; Don't know, ID = Inclined to Disagree, and SD = Strongly Disagree.

\section{Scanning Obstacles}

Which of the following six factors had been an obstacle to efforts to $\quad$ SA collect/receive information from the environment

(1) Government bureaucracy (X58)

(2) Information in a different language(X58) 


\begin{tabular}{|l|l|l|l|l|l|}
\hline (3) Inadequate management education/training, (X60) & & & & & \\
\hline (4) Uncertainty regarding government long-term policies, (X61) & & & & & \\
\hline (5) Absence of data sources, (X62) & & & & & \\
\hline (6) The quality of available information(X63 ) & & & & & \\
\hline (7) Decentralization of decision making (X64) & & & & & \\
\hline $\begin{array}{l}\text { Notes: } \\
\text { SA }=\text { Strongly Agree, IA = Inclined to Agree, UD = Undecided; Don't know, ID = Inclined to Disagree, and SD = } \\
\text { Strongly Disagree }\end{array}$
\end{tabular}

\section{Copyrights}

Copyright for this article is retained by the author(s), with first publication rights granted to the journal.

This is an open-access article distributed under the terms and conditions of the Creative Commons Attribution license (http://creativecommons.org/licenses/by/4.0/). 